\title{
Transformations of mercury in processes of solid fuel combustion - review
}

\author{
Marianna Czaplicka, Halina Pyta* \\ Institute of Environmental Engineering Polish Academy of Sciences in Zabrze, Poland
}

*Corresponding author's e-mail: halina.pyta@ipis.zabrze.pl

Keywords: mercury, coal combustion, homogeneous reactions, heterogeneous reaction, flue gases.

\begin{abstract}
The paper presents current reports on kinetics and mechanisms of reactions with mercury which take place in the exhaust gases, discharged from the processes of combustion of solid fuels (coals). The three main stages were considered. The first one, when thermal decomposition of $\mathrm{Hg}$ components takes place together with formation of elemental mercury $\left(\mathrm{Hg}^{0}\right)$. The second one with homogeneous oxidation of $\mathrm{Hg}^{0}$ to $\mathrm{Hg}^{2+}$ by other active components of exhaust gases (e.g. $\mathrm{HCl}$ ). The third one with heterogeneous reactions of gaseous mercury (the both - elemental and oxidised $\mathrm{Hg}$ ) and solid particles of fly ash, leading to generation of particulate-bound mercury $\left(\mathrm{Hg}_{\mathrm{p}}\right)$. Influence of exhaust components and their concentrations, temperature and retention time on the efficiency of mercury oxidation was determined. The issues concerning physical (gas-solid) and chemical speciation of mercury (fractionation $\mathrm{Hg}^{0}-\mathrm{Hg}^{2+}$ ) as well as factors which have influence on the mercury speciation in exhaust gases are discussed in detail.
\end{abstract}

\section{Introduction}

Mercury is released into the environment from natural (e.g. volcanic eruptions) and anthropogenic sources. It is estimated that, in a global scale, mercury emitted as a result of human activity constitutes between $30 \%$ and $60 \%$ of this element's total emission into the environment (Pacyna et al. 2016). These data prove mercury to be a factor of significant detrimental effect on the ecosystem.

A survey of European mercury emission sources, conducted under projects financed by the United Nations Economic Commission for Europe (UNECE) through the Convention on Long-Range Transboundary Air Pollution (LRTAP), the Baltic Marine Environment Protection Commission, also known as Helsinki Commission (HELCOM), and the Oslo and Paris Commissions (OSPAR) for the Protection of the Marine Environment of the North-East Atlantic, has identified solid fuel combustion processes to be the main anthropogenic sources of mercury. It has been established that emission of $\mathrm{Hg}$ from commercial power installations accounts for more than 26\% (63.5 tonnes) of the total $\mathrm{Hg}$ emission in $\mathrm{EU}$ countries, whereas uncontrolled emission from processes of fuel combustion in household furnaces is at the level of around $20 \%$ (48.8 tonnes) (Pacyna et al. 2006). For comparison, in the USA, it is estimated that $41.6 \%$ (48.7 tons per year) of mercury emission into the air is caused by fuel combustion in utility boilers (Praveen 2003).

Due to mercury toxicity, the U.S. Congress placed this element in the 1990 Clean Air Act Amendments (CAAA) as a hazardous air pollutant. The Clean Air Mercury Rule (CAMR) would have placed the limit values on the mercury emissions from coal-fired power plants; however the U.S. Court of Appeals, District Columbia vacated them in 2008. Final Mercury and Air Toxics Standards (MATS) from coal-fired power plants have been issued by the U.S Environmental Protection Agency (EPA) in 2011 (US EPA 2011, Wilcox et al. 2012). And similarly, in 2006 the Canadian Council of Ministers of the Environment (CCME) endorsed the Canada - wide Standards (CWSs) for the coal-fired electric power generation sector. The CWSs set targeted emissions caps for individual provinces for the year 2010 with the possibility of more stringent reductions by 2018 (CCME, 2006).

The USA and Canada have set stringent emission limits for coal-fired plants which require many plants to install mercury-specific control technologies. Other countries, such as the Member States of the European Union and some countries in Asia (Japan, Korea, China) are taking a less stringent legislative approach based on the mercury co-benefit control technologies, used for reduction of other pollutants emissions (particulate matter $\mathrm{PM}$, sulphur dioxide $\mathrm{SO}_{2}$ and nitrogen oxides $\mathrm{NO}_{\mathrm{x}}$ ) (Rallo et al 2012, Sloss 2012).

Because of the diversified properties of individual mercury forms, it is important to determine the speciation of this element. In natural environments mercury exists both in inorganic $\left(\mathrm{Hg}^{0}, \mathrm{Hg}^{+2}\right)$ and organic forms (e.g. methylmercury). Individual forms differ considerably from one another in terms of physical and chemical properties (Table 1). Compared to elemental mercury, $\mathrm{Hg}^{2+}$ (except for $\mathrm{HgS}$ ) and organometallic 
Table 1. Properties of mercury compounds (adopted from Kabata-Pendias and Pendias 1999)

\begin{tabular}{|l|c|c|c|c|c|c|}
\hline \multicolumn{1}{|c|}{ Parameter } & $\mathrm{Hg}^{0}$ & $\mathrm{HgCl}_{2}$ & $\mathrm{HgO}$ & $\mathrm{HgS}$ & $\mathrm{CH}_{3} \mathrm{HgCl}$ & $\left(\mathrm{CH}_{3}\right)_{2} \mathrm{Hg}$ \\
\hline Melting point, ${ }^{\circ} \mathrm{C}$ & -39 & 277 & $\begin{array}{c}\text { degradation } \\
\text { at } 500^{\circ} \mathrm{C}\end{array}$ & $\begin{array}{c}584 \\
\text { (sublimation) }\end{array}$ & $\begin{array}{c}167 \\
\text { (sublimation) }\end{array}$ & - \\
\hline Boiling point, ${ }^{\circ} \mathrm{C}$ & $357(1 \mathrm{~atm})$ & $303(1 \mathrm{~atm})$ & - & - & - & $96(1 \mathrm{~atm})$ \\
\hline Vapor pressure, $\mathrm{Pa}$ & $\begin{array}{c}0.180 \\
\left(20^{\circ} \mathrm{C}\right)\end{array}$ & $\begin{array}{c}899 \times 10^{-3} \\
\left(20^{\circ} \mathrm{C}\right)\end{array}$ & $\begin{array}{c}9.20 \times 10^{-12} \\
\left(25^{\circ} \mathrm{C}\right)\end{array}$ & - & $\begin{array}{c}1.76 \\
\left(25^{\circ} \mathrm{C}\right)\end{array}$ & $\begin{array}{c}8.30 \times 10^{3} \\
\left(24^{\circ} \mathrm{C}\right)\end{array}$ \\
\hline Solubility in water, g/dm & $\begin{array}{c}49.4 \times 10^{-6} \\
\left(20^{\circ} \mathrm{C}\right)\end{array}$ & $\begin{array}{c}66 \\
\left(20^{\circ} \mathrm{C}\right)\end{array}$ & $\begin{array}{c}5.3 \times 10^{-2} \\
\left(25^{\circ} \mathrm{C}\right)\end{array}$ & $\begin{array}{c}\sim 2 \times 10^{-24} \\
\left(25^{\circ} \mathrm{C}\right)\end{array}$ & $\begin{array}{c}\sim 5-6 \\
\left(25^{\circ} \mathrm{C}\right)\end{array}$ & $\begin{array}{c}2.95 \\
\left(24^{\circ} \mathrm{C}\right)\end{array}$ \\
\hline Octanol-water partition coefficient & 4.2 & 0.5 & - & - & 2.5 & 180 \\
\hline
\end{tabular}

compounds of mercury are less volatile, more water soluble, and more chemically reactive. The differences in their physical and chemical properties, and particularly the good water solubility of $\mathrm{Hg}^{2+} \mathrm{X}$, result in more efficient removal of these compounds in conventional flue gas purification systems when compared to the elemental mercury. The knowledge of physical and chemical transformation of mercury in combustion processes allows to select the right method of reduction of mercury emission to the atmosphere and decide whether more appropriate would be application of particulate emission control devices (fabric filters FFs, electrostatic precipitators ESPs) or adsorption methods (in-duct sorbent injection, sorbent bed technologies) or absorption techniques (wet scrubbers with or without additives), etc. (Józewicz 2007, Hlawiczka and Fudala 2008).

The speciation of mercury in flue gases is crucial for reducing its emissions to the atmosphere. The exhaust from coal combustion may contain mercury in a particulate-bound form $\left(\mathrm{Hg}_{\mathrm{n}}\right)$ as well as in a gaseous elemental $\left(\mathrm{Hg}^{0}\right)$ and oxidized $\left(\mathrm{Hg}^{+2}\right)$ forms, whereas there are no data confirming the presence of organometallic compounds of mercury in flue gas. The predominant form of oxidized mercury in flue gas are halides, mainly $\mathrm{HgCl}_{2}$ as well as $\mathrm{HgBr}_{2}$ and $\mathrm{HgI}_{2}$, occurring in both, the gaseous phase and particulate-bound form. Flue gas may also contain $\mathrm{HgO}_{(\mathrm{g})}$ as well as particulate-bound mercury compounds, such as $\mathrm{Hg}^{2+} \mathrm{X}$ (where $\mathrm{X}$ stands for $\mathrm{SO}_{4}^{2-}, \mathrm{S}^{2-}, \mathrm{O}^{2-}$ ) (Praveen 2003, Wilcox et al. 2012). When coal is combusted in low capacity domestic heating units only about $50 \%$ of mercury contained in coal is emitted to the air in gaseous form (Hlawiczka et al. 2003). The second half of the mercury is present in particulate matter $\left(\mathrm{Hg}_{\mathrm{p}}\right)$, partially trapped in chimney duct. Data available in the relevant literature suggest that $\mathrm{Hg}_{\mathrm{p}}$ present in ambient air of urban and industrial areas accounts for up to $15 \%$ of the total atmospheric mercury (Pyta et al. 2009, Bełdowska et al. 2012, Nowak et al. 2013, Nowak et al. 2014).

\section{Mercury content in coals}

Mercury exists in coal as inorganic and organic components. However, studies on the determination of $\mathrm{Hg}$ in organic matter in coal are quite limited (Kolker et al., 2006). Mercury can be associated with pyrite $\left(\mathrm{FeS}_{2}\right)$, sphalerite, and cinnabar $(\mathrm{HgS})$. Sometimes it can occur in a form of elemental (metallic) mercury or in forms bound to coal macerals. The studies conducted by Zheng et al. (2007) indicated that this element was mainly found in the form of sulphides $(40 \%$ of total $\mathrm{Hg}$ content) and organic matter (30\%). Mercury is a chalcophile element, with great affinity to sulphur-containing components, generally incorporated in pyrite (Kolker et al. 2006, Mukherjee et al. 2008). Therefore, the conventional coal cleaning process may be an effective method of removing the substantial amounts of $\mathrm{Hg}$ as it occurs in coarse-grained pyrite (Finkelman, 1994).

Mercury is a coal micro-component. The average $\mathrm{Hg}$ content varies significantly for various countries from 0.01 to over $1.0 \mathrm{mg} / \mathrm{kg}$ (Table 2). But its higher content $(>1.0 \mathrm{mg} / \mathrm{kg}$ ) is quite rare. There are some coals highly enriched in $\mathrm{Hg}$ (and other sulfophile elements such as: $\mathrm{As}, \mathrm{Se}, \mathrm{Pb}, \mathrm{Cu}$, and $\mathrm{Zn}$ ). Such coals are located in the Donbas (Ukraine), particularly in the Donetsk coal basin, Russian Far East, Southern China, Appalachian basin and Texas (USA) (Toole-O'Neil et al. 1999, Yudovich and Ketris 2005a). Yudovich et al. (2005a) reported that $\mathrm{Hg}$ content in Russian Pacific coals was up to $15 \mathrm{mg} / \mathrm{kg}$. The coals from Ukrainian Donbas contained on average $0.12-2.37 \mathrm{mg} / \mathrm{kg}$ of mercury, but some samples contained almost $60 \mathrm{mg} / \mathrm{kg}$ of mercury (Yudovich et al. 2005a, Wichliński et al. 2013). Such high mercury concentrations were confirmed by Kolker et al. (2009) who reported that the Donbas coals contained $0.02-26 \mathrm{mg} / \mathrm{kg}$ of mercury.

Mercury content in coals generally depends on coal density and the presence of sulphur (Mukherjee et al. 2008). When coals have high density, e.g. are buried deep in the ground they often contain a high concentration of $\mathrm{Hg}$. This concerns Korean anthracite coals (Park et al. 2006) and Appalachian bituminous coals (Ruch et al. 1974). Yudovich and Ketris (2005a, 2005b) concluded that there is strong evidence that high-sulphur coals usually contain more $\mathrm{Hg}$, mainly in the pyritic form. In the extremely Hg-enriched Donbas coals, both sulphides ( $\mathrm{HgS})$ and metallic mercury $\left(\mathrm{Hg}^{0}\right)$ occur. In low-sulphur coals, which are generally poor in $\mathrm{Hg}$, two $\mathrm{Hg}$ forms dominate: organic and sulphide mercury (Yudovich and Ketris 2005a).

\section{Mercury speciation in flue gases}

EPA's Information Collection Request (ICR) to coal-burning utilities indicated that on average $60 \%$ of $\mathrm{Hg}$ entering a power plant is emitted to the air and $40 \%$ is captured (Kilgroe et al. 2001). Numerous studies showed that percentage emissions of mercury for individual plants varied widely (from 5\% to $90 \%$ of $\mathrm{Hg}$ entering with coal) depending on the coal composition and conditions of combustion process (Chow et al. 1994, Jones 1994, Galbreath and Zygarlicke 1996, Widmer et al. 1998, Galbreath and Zygarlicke 2000, Sakulpitakphon et al. 2000, Senior et al. 2000, Dunham et al. 2003, Mardon and Hower 
Table 2. Content of $\mathrm{Hg}$ in coals (adopted from UNEP 2016)

\begin{tabular}{|c|c|c|c|c|}
\hline \multirow{2}{*}{$\begin{array}{l}\text { Country } \\
\text { (Region) }\end{array}$} & \multirow{2}{*}{ Coal type } & \multicolumn{2}{|c|}{ Concentration of $\mathrm{Hg}, \mathrm{mg} / \mathrm{kg}$} & \multirow{2}{*}{ Reference } \\
\hline & & Mean & Range & \\
\hline Australia & Bituminous & 0.075 & $0.01-0.31$ & Nelson 2007, Tewalt et al. 2010 \\
\hline Argentina & Bituminous & 0.19 & $0.02-0.96$ & UNEP 2010, Tewalt et al. 2010 \\
\hline Brazil & $\begin{array}{l}\text { Bituminous } \\
\text { Subbituminous }\end{array}$ & $\begin{array}{l}0.20 \\
0.30\end{array}$ & $\begin{array}{l}0.04-0.81 \\
0.06-0.94\end{array}$ & UNEP 2010, Tewalt et al. 2010 \\
\hline Canada & - & 0.058 & $0.033-0.12$ & Tewalt et al. 2010 \\
\hline Chile & $\begin{array}{l}\text { Bituminous } \\
\text { Subbituminous }\end{array}$ & $\begin{array}{c}0.21 \\
0.033\end{array}$ & $\begin{array}{c}0.03-2.2 \\
0.022-0.057\end{array}$ & Tewalt et al. 2010 \\
\hline China & Bitumin./Subbitumin. & 0.17 & $0.01-2.248$ & Zhang et al. 2012, UNEP 2011 \\
\hline Colombia & Subbituminous & 0.069 & $0.02-0.17$ & UNEP 2010 \\
\hline Czech Rep. & $\begin{array}{l}\text { Lignite } \\
\text { Bituminous }\end{array}$ & $\begin{array}{l}0.338 \\
0.126\end{array}$ & $\begin{array}{c}<0.03-0.79 \\
0.03-0.38\end{array}$ & UNEP 2010, Tewalt et al. 2010 \\
\hline Germany & $\begin{array}{l}\text { Bituminous } \\
\text { Lignite }\end{array}$ & $\begin{array}{c}0.354 \\
0.05\end{array}$ & $\begin{array}{c}0.7-1.4 \\
\text { Max: } 0.09\end{array}$ & $\begin{array}{l}\text { Pirrone et al. } 2001 \\
\text { UNEP } 2016\end{array}$ \\
\hline Great Britain & Bituminous & 0.216 & $0.012-0.6$ & Tewalt et al. 2010 \\
\hline Hungary & $\begin{array}{c}\text { Lignite } \\
\text { Subbituminous } \\
\text { Bituminous }\end{array}$ & $\begin{array}{l}0.242 \\
0.138 \\
0.354\end{array}$ & $\begin{array}{c}0.075-0.44 \\
0.04-0.31 \\
0.091-1.2\end{array}$ & Tewalt et al. 2010 \\
\hline India & $\begin{array}{l}\text { Bitominous } \\
\text { Lignite }\end{array}$ & $\begin{array}{l}0.106 \\
0.071\end{array}$ & $\begin{array}{c}0.02-0.86 \\
0.053-0.093\end{array}$ & Tewalt et al. 2010, UNEP 2013a \\
\hline Indonesia & $\begin{array}{l}\text { Subbituminous } \\
\text { Lignite }\end{array}$ & $\begin{array}{l}0.03 \\
0.11\end{array}$ & $\begin{array}{l}0.01-0.05 \\
0.02-0.19\end{array}$ & $\begin{array}{l}\text { US EPA } 2002 \\
\text { UNEP 2010, Tewalt et al. } 2010\end{array}$ \\
\hline Japan & Bituminous & 0.045 & $0.01-0.21$ & Ito et al. 2006 \\
\hline Kazakhstan & Bituminous & 0.08 & $<0.03-0.14$ & Tewalt et al. 2010 \\
\hline New Zeland & $\begin{array}{c}\text { Bituminous } \\
\text { Subbituminous }\end{array}$ & $\begin{array}{l}0.073 \\
0.082 \\
\end{array}$ & $\begin{array}{c}0.03-0.1 \\
0.062-0.13\end{array}$ & Tewalt et al. 2010 \\
\hline Mongolia & Bituminous & 0.097 & $0.02-0.22$ & Tewalt et al. 2010 \\
\hline Poland & $\begin{array}{l}\text { Bituminous } \\
\text { Bituminous } \\
\quad \text { Lignite } \\
\text { Bituminous } \\
\quad \text { Lignite }\end{array}$ & $\begin{array}{l}0.085 \\
0.100 \\
0.250 \\
- \\
-\end{array}$ & $\begin{array}{c}0.013-0.163 \\
0.05-0.150 \\
0.120-0.370 \\
0.013-0.156 \\
0.079-0.230\end{array}$ & $\begin{array}{l}\text { Bojakowska \& Sokołowska } 2001 \\
\text { Wojnar \& Wisz } 2006 \\
\text { Wojnar \& Wisz } 2006 \\
\text { Wichliński et al. } 2013 \\
\text { Wichliński et al. } 2013\end{array}$ \\
\hline Romania & Lignite/Subbitumin. & 0.21 & $0.07-0.46$ & UNEP 2010 \\
\hline Russia & Bitumin./Subbitumin. & 0.12 & $<0.02-0.25$ & Romanov et al. 2012, UNEP 2013b \\
\hline Slovak Rep. & $\begin{array}{l}\text { Bitominous } \\
\text { Lignite }\end{array}$ & $\begin{array}{c}0.08 \\
0.057\end{array}$ & $\begin{array}{c}0.03-0.13 \\
0.032-0.14 \\
\end{array}$ & $\begin{array}{l}\text { UNEP } 2010 \\
\text { Tewalt et al. } 2010\end{array}$ \\
\hline South Africa & Bituminous & 0.157 & $0.023-0.1$ & Leaner et al. 2009, Tewalt et al. 2010 \\
\hline South Korea & Anthracite & 0.30 & $0.02-0.88$ & UNEP 2010 \\
\hline Tanzania & Bituminous & 0.12 & $0.03-0.22$ & UNEP 2010 \\
\hline Turkey & Lignite & 0.12 & $0.03-0.66$ & Tewalt et al. 2010 \\
\hline $\begin{array}{l}\text { Ukraine (Donbas): } \\
\text { Donetsk-Makeevsky } \\
\text { Krasnoarmeevsky } \\
\text { Alma-Marievsky } \\
\text { Charabowska area }\end{array}$ & Bituminous & $\begin{array}{l}0.99 \\
2.37 \\
0.12 \\
0.88\end{array}$ & $\begin{array}{l}0.17-3.09 \\
<0.01-6.0 \\
<0.01-8.4 \\
0.40-1.30\end{array}$ & $\begin{array}{l}\text { Kolker et al. 2009, } \\
\text { Wichliński et al. } 2013\end{array}$ \\
\hline USA & $\begin{array}{c}\text { Subbituminous } \\
\text { Lignite } \\
\text { Bituminous } \\
\text { Anthracite }\end{array}$ & $\begin{array}{l}0.10 \\
0.15 \\
0.21 \\
0.23 \\
\end{array}$ & $\begin{array}{c}0.01-8.0 \\
0.03-1.0 \\
<0.01-3.3 \\
0.16-0.30 \\
\end{array}$ & US EPA 1997 \\
\hline Vietnam & Anthracite & 0.28 & $<0.02-1.14$ & UNEP 2010 \\
\hline
\end{tabular}


2004, Lee et al. 2006, Zhao et al. 2006, Lopez-Anton et al. 2010). They also showed that $\mathrm{Hg}$ concentrations in stack gases varied in a wide range between 3 and $70 \mu \mathrm{g} / \mathrm{m}^{3}$.

Mercury in coal-fired power plants is found mainly as gaseous elemental $\left(\mathrm{Hg}^{0}\right)$ and oxidized $\left(\mathrm{Hg}^{2+}\right)$ form and as particulate mercury $\left(\mathrm{Hg}_{\mathrm{p}}\right)$ bound with fly ash. Depending on its mode of occurrence, mercury can be captured by different types of air pollution control devices (APCDs). Flue gas composition plays an important role in $\mathrm{Hg}$ speciation. As the combustion gases are cooled, homogenous reactions (gas-gas) and heterogeneous interactions with fly ash (gas-solid) occur affecting the mercury oxidation and its removal by APCDs.

ICR data on coal-burning utilities indicated very little mercury removal within pulverized coal-fired (PC) boilers. The level of mercury oxidation at the exit of PC boiler was increased for higher coal chlorine contents and lower flue gas temperatures. Therefore, $\mathrm{Hg}$ removals within $\mathrm{PC}$ boilers equipped with cold-side ESPs averaged 27\%, compared to 4\% for hot-side ESPs (Pavlish et al. 2003). Mercury removals for FFs were generally higher than for ESPs, averaging 58\%, owing to enhanced heterogeneous $\mathrm{Hg}$ oxidation (longer gas-solid contact time) (Cao et al. 2008). Elemental mercury is the most difficult to capture, but selective catalytic reduction units (SCRs) are able to convert elemental mercury to oxidized form allowing it to be subsequently captured by wet flue gas desulphurization systems (FGDs). Both wet and dry FGD systems without SCR removed $80-90 \%$ of the oxidized mercury, but elemental mercury was not affected (Pavlish et al. 2003). Only the combination of SCRs and FGDs was considered as an effective $\mathrm{Hg}$ control method (Józewicz 2007, Pan et al. 2013).

It has been proved that the content of elemental mercury in total mercury emitted from a $190 \mathrm{MW}$ PC boiler ranged from $30 \%$ to $70 \%$ when SCR was applied (Wu et al. 2010). Wu and co-authors also highlighted oxidation efficiency reaching $71 \%$ in the SCR systems. By means of the wet FGD without SCR, it was possible to capture $54.9-68.8 \%$ of total mercury, while with the SCR system the mercury removal efficiencies ranged from $78 \%$ to $90.2 \%$ (Winberg et al. 2004, Eom et al. 2008, Strege 2008).

Review of ICR data proved high mercury removals, averaging $86 \%$, in fluidized-bed combustors (FBCs) with FFs (Pavlish et al 2003). This was possible due to efficient mercury capture on high-carbon fly ash. Fly ash structure (the specific surface area) is also essential factor of lower $\mathrm{Hg}$ emission rates in the FBC units. The specific surface area of fly ash from the FBCs (on average $15 \mathrm{~m}^{2} / \mathrm{g}$ ) was generally higher than those from PC boilers $\left(1-10 \mathrm{~m}^{2} / \mathrm{g}\right.$ ) (Cao et al. 2008). The percentage of $\mathrm{Hg}^{0}$ in the total $\mathrm{Hg}$ emission from the FBCs with fabric filtration was higher than for PC boilers equipped with FFs, averaging 56\% versus 23\% (Pavlish et al 2003). This is probably due to the removal of chlorine from flue gas by bed calcium (the limestone in FBC) before it can promote the oxidation of mercury.

Basic parameters which affect chemical and physical speciation of mercury are the process temperature, the content of chlorine, sulphur, iron, and calcium in coals as well as the concentration of $\mathrm{HCl}$ and ammonia in flue gas (Sliger et al. 2000, Pavlish et al. 2003, Zhuang et al. 2004, Lee et al. 2006, Zhao et al. 2006). It is estimated that more than $85 \%$ of the mercury in flue gas from combustion of coal with low-chlorine content $(\mathrm{Cl}<150 \mathrm{ppm})$ represents elemental mercury. An opposite trend may be observed in combustion of the coals of chlorine content above 150-200 ppm, where only $10 \%$ of the mercury in flue gas was found in the form of $\mathrm{Hg}^{0}$ (Hall et al. 1991).

It is commonly acknowledged that, at combustion temperatures, the mercury evaporates completely from coal in the form of $\mathrm{Hg}^{0}$. It is only after the flue gas is cooled down to a temperature below $600^{\circ} \mathrm{C}$ that elemental mercury vapours react with other flue gas components, consequently leading to the formation of oxidized forms $\left(\mathrm{Hg}^{+2}\right)$ and $\mathrm{Hg}_{\mathrm{p}}$ forms bound with fly ash (Fujiwara et al. 2002, Pavlish et al. 2003, Zhuang et al. 2004). The mechanism of the mercury oxidation in the presence of chlorine has not yet been unambiguously determined, but numerous studies show both homo- and heterogeneous mechanisms of the reaction between mercury and other flue gas components (Niksa et al. 2001, Lee et al. 2006, Zhao et al. 2006). The scheme of individual reactions depends on the coal characteristics (mineral and chemical composition), flue gas composition, process conditions, as well as the rate of flue gas cooling (Frandsen et al. 1994, Ariya et al. 2002, Li et al. 2003, Senior and Johnson 2005, Wichliński et al. 2014). For example, Jang and co-workers (Jang et al. 2014) proved the impact of limestone injection on the kinetics of mercury oxidation. They indicated that the gaseous oxidized mercury was more reactive with the limestone injected in the conditions of oxy-fuel combustion and the formation of particulate mercury from the oxy-fuel combustion was more efficient than from the air combustion.

Most studies indicate a strong correlation between the chlorine content in coal and the concentrations of $\mathrm{Hg}^{+2}$ and $\mathrm{Hg}^{0}$ in flue gas. It has been found that an increase in the chlorine content in fuel is accompanied by a decrease in $\mathrm{Hg}^{0}$ in the total volume of mercury emitted from the combustion process (Hall et al. 1991, Niksa et al. 2001, Pavlish et al. 2003, Senior and Johnson 2005, Cauch et al. 2008, Jang et al. 2014). While studying transformations of $\mathrm{Hg}$ in the process of combustion of different coal ranks, Senior and Johnson (Senior and Johnson 2005) concluded that, in the case of lignite and subbituminous coals, the higher chlorine content in fuel brought a proportional decline in the $\mathrm{Hg}^{0}$ concentration in the flue gas, with a simultaneous increase of oxidized $\mathrm{Hg}$ concentration. However, there were no such proportional relations between the concentrations of examined $\mathrm{Hg}$ forms for bituminous coals. Fujiwara et al. confirmed the aforementioned conclusions and described a complex mechanism of homogeneous and heterogeneous mercury oxidation (Fujiwara et al. 2002). The meaning of chlorine in reactions with mercury in combustion processes can be explained by accurate determination of the functions of all chlorine forms, i.e. atomic chlorine $\mathrm{Cl}$, molecular chlorine $\mathrm{Cl}_{2}$, as well as $\mathrm{HCl}$, both in terms of physical and chemical speciation. There is a significant impact of temperature and composition of flue gas on the kinetics and the mechanism of the $\mathrm{Hg}$ oxidation reaction (Rizeq et al. 1994, Widmer et al. 1998, Galbreath and Zygarlicke 2000, Ariya et al. 2002, Pavlish et al. 2003, Lee et al. 2006, Cauch et al. 2008, Jang et al. 2014, Ticknor et al. 2014). In a majority of cases, it is assumed that in the processes of thermal decomposition at the combustion temperature the chlorine in coal is released in a form of strongly reactive atomic chlorine (Horne et al. 1968, Frandsen et al. 1994, Widmer et al. 1998, Procaccini et al. 2000, 
Ariya et al. 2002, Li et al. 2003, Xu et al. 2003, Wichliński et al. 2014, Jang et al. 2014). Cooling of the flue gas causes reactions which result in the formation of $\mathrm{Cl}_{2}$ and $\mathrm{HCl}$. The kinetics of these reactions depends on the rate of suppression of excited states and the stoichiometry (Senior et al. 2000, Xu et al. 2003, Agarwal and Stenger 2007, Cauch et al. 2008). Despite the very short lifetime of a chlorine atom, kinetic data show that the reaction between $\mathrm{Cl}$ and $\mathrm{Hg}$ atoms represents the dominating homogeneous reaction of oxidation, kinetically restricted by the presence of other flue gas components, mainly $\mathrm{CO}, \mathrm{H}_{2} \mathrm{O}$, NO, and $\mathrm{SO}_{2}$ (Laudal et al. 2000, Senior et al. 2000, Niksa et al. 2002, Zhuang et al. 2007a, Zhuang et al. 2007b).

\section{Homogeneous reactions}

In the combustion of coals with low chlorine content under non-equilibrium conditions, $\mathrm{Hg}^{0}$ may become oxidized to $\mathrm{HgCl}_{2}$ and $\mathrm{HgO}$. Senior and co-authors (Senior et al. 2000) showed that formation of $\mathrm{HgO}$ is crucial for coals of low chlorine content. It is estimated that in the low temperature of flue gas $\left(<400^{\circ} \mathrm{C}\right)$, about $10 \%$ of mercury may take the form of an oxide, i.e. $\mathrm{HgO}$ (Rizeq et al. 1994). Relying on theoretical studies based on quantum chemistry (MP2 programme, SDD method), $\mathrm{Xu}$ and co-authors (Xu et al. 2003) proposed the kinetics of potential reactions leading to formation and decomposition of $\mathrm{HgO}$ (Table 3). They found that with the $\mathrm{O}_{2}$ concentration of $10 \% \mathrm{v} / \mathrm{v}$, from $1.5 \%$ to $6.0 \%$ of total $\mathrm{Hg}$ was oxidized to $\mathrm{HgO}$.

The presence of chlorine in the combustion process has some influence on the kinetics and the mechanism of homogeneous reactions. Kinetic data of the elemental mercury oxidation indicate that the direct reaction between $\mathrm{Hg}$ and $\mathrm{Cl}_{2}$ (at the $\mathrm{Cl}$ concentration of $10 \mathrm{ppm}$ ) in a flow reactor within the range of temperatures from $200^{\circ} \mathrm{C}$ to $700^{\circ} \mathrm{C}$ and absence of other compounds in gases is characterized by a constant rate of $1.07 \times 10^{-15} \mathrm{~cm}^{3} / \mathrm{mol} \mathrm{s}$ (Hall et al. 1991). However, due to the high activation energy of $98.29 \mathrm{kcal} / \mathrm{mol}$ (US EPA Grant No. $\mathrm{R} 828168,2004)$, a direct reaction between $\mathrm{Hg}$ and $\mathrm{HCl}$, leading to the formation of $\mathrm{HgCl}$, is impossible (Fuente-Cuesta et al. 2012). The mechanisms of $\mathrm{HgCl}_{2}$ formation via homogeneous reactions of $\mathrm{Hg}^{0}$ and atomic chlorine are suggested to proceed according to the following equations (Niksa et al. 2001, Li et al. 2003, Zhuang et al. 2004, Zhao et al. 2006):

$$
\begin{gathered}
\mathrm{Hg}+\mathrm{Cl} \rightarrow \mathrm{HgCl} \\
\mathrm{HgCl}+\mathrm{HCl} \rightarrow \mathrm{HgCl}_{2}+\mathrm{H} \\
\mathrm{HgCl}+\mathrm{Cl}_{2} \rightarrow \mathrm{HgCl}_{2}+\mathrm{Cl} \\
\mathrm{HgCl}+\mathrm{Cl} \rightarrow \mathrm{HgCl}_{2}
\end{gathered}
$$

According to kinetic conditions, atomic chlorine may occur at flame temperature, particularly at high $\mathrm{Cl}_{2}$ concentration. It is only after cooling down of the gas that the chlorine atoms react with $\mathrm{HCl}$ to form $\mathrm{Cl}_{2}$ and hydrogen. Reaction (1) is characterized by low activation energy and may take place in room temperature at a constant rate of 1.95 $\pm 1.05 \times 10^{13} \mathrm{~cm}^{3} / \mathrm{mol} \mathrm{s}$ (Horne et al. 1968); the reaction has hampering influence on the mercury oxidation (Ariya et al. 2002, Li et al. 2003, Pavlish et al. 2003, Zhao et al. 2006). Sliger and co-workers (Sliger et al. 2000) proved that reaction (2) proceeds very slowly within the range of temperatures from $620^{\circ} \mathrm{C}$ to $1700^{\circ} \mathrm{C}$, therefore, its contribution to oxidation of mercury is negligible. Reaction (3) becomes hindered under conditions of increased temperatures $\left(>600^{\circ} \mathrm{C}\right)$. Reaction (4), on the other hand, is exothermic and only takes place next to the boundary of the energy barrier of active collisions. The foregoing considerations indicate that only two reactions with chlorine are responsible for the oxidation of $\mathrm{Hg}$, and that atomic chlorine takes part in both of them. However, it should be noted that reactions (1) and (4) take place only in the area where (i) superequilibrium concentrations of $\mathrm{Cl}$ is observed (for temperature $\mathrm{T}>400^{\circ} \mathrm{C}$ ) and where (ii) $\mathrm{HgCl}_{2}$ represents the prevalent equilibrium product $\left(\mathrm{T}<700^{\circ} \mathrm{C}\right)$. This process model is recommended in mercury oxidation at a temperature above $800^{\circ} \mathrm{C}$. Other homogeneous reactions with $\mathrm{O}_{2}, \mathrm{NO}_{2}$, and $\mathrm{NO}$, and occurring at a temperature above $800^{\circ} \mathrm{C}$, are limited in their extent due to kinetic constraints (Hall et al. 1991). When the flue gas temperatures are below $800^{\circ} \mathrm{C}$, other flue gas components, such as $\mathrm{HCl}, \mathrm{Cl}_{2}, \mathrm{SO}_{2}, \mathrm{H}_{2} \mathrm{O}$, and $\mathrm{NO}$, take indirect or direct part in oxidation reactions (Hall et al. 1991, Widmer et al. 1998, Senior et al. 2000, Sliger et al. 2000, Xu et al. 2003, Zhuang et al. 2007, Cauch et al. 2008). Jang and co-authors (Jang et al. 2014) reported that in combustion, $\mathrm{SO}_{2}$ reacts with oxidized mercury $\left(\mathrm{HgCl}_{2}\right)$, generating finally particulate mercury in a form of $\mathrm{HgSO}_{4(\mathrm{~s})}$. Fuente-Cuesta et al. (2012) suggested that $\mathrm{O}_{2}$ has a synergistic effect on mercury oxidation, not only affecting it directly, but also via $\mathrm{NO}_{2}$.

At lower temperatures $\left(<450^{\circ} \mathrm{C}\right)$, mercury oxidation is determined by the following reaction (Niksa et al. 2001, Fujiwara et al. 2002, Zhao et al. 2006):

$$
\mathrm{Hg}+\mathrm{Cl}_{2} \rightarrow \mathrm{HgCl}_{2}
$$

Hall et al. (1991) have suggested that reaction (5) is characterized by a constant rate of $\mathrm{k}=3.4 \times 10^{9} \mathrm{~cm}^{3} / \mathrm{mol} \mathrm{s}$ for gases containing only mercury and $10 \mathrm{ppm}$ of $\mathrm{Cl}_{2}$. However this rate depends also on other flue gas components, i.e. $\mathrm{CO}_{2}$, $\mathrm{H}_{2} \mathrm{O}$ and $\mathrm{O}_{2}$.

The impact of $\mathrm{HCl}$ on the mercury oxidation reaction has been extensively discussed in many papers (Hall et al. 1991,

Table 3. Kinetic parameters for mercury oxidation (adopted from Xu et al. 2003)

\begin{tabular}{|c|c|c|c|}
\hline No & Reaction & Reaction rate constant, $\mathrm{cm}^{3} /(\mathrm{mol} \mathrm{s})$ & Activation energy, kcal/mol \\
\hline 1 & $\mathrm{Hg}+\mathrm{ClO} \rightarrow \mathrm{HgO}+\mathrm{Cl}$ & $1.38 \times 10^{12}$ & 8.32 \\
\hline 2 & $\mathrm{Hg}+\mathrm{ClO}_{2} \rightarrow \mathrm{HgO}+\mathrm{ClO}$ & $1.87 \times 10^{7}$ & 51.27 \\
\hline 3 & $\mathrm{Hg}+\mathrm{N}_{2} \mathrm{O} \rightarrow \mathrm{HgO}+\mathrm{N}_{2}$ & $5.08 \times 10^{10}$ & 59.81 \\
\hline 4 & $\mathrm{HgO}+\mathrm{HCl} \rightarrow \mathrm{HgCl}+\mathrm{OH}$ & $9.63 \times 10^{4}$ & 8.92 \\
\hline 5 & $\mathrm{HgO}+\mathrm{HOCl} \rightarrow \mathrm{HgCl}+\mathrm{HO}_{2}$ & $4.11 \times 10^{13}$ & 60.47 \\
\hline
\end{tabular}


Widmer et al. 1998, Laudal et al. 2000, Senior et al. 2000, Sliger et al. 2000, Li et al. 2003). HCl is formed in high-temperature combustion zones as a result of transformation of the chlorine which is derived from coal. According to Deacon's mechanism, $\mathrm{HCl}$ in cooled flue gas is partially oxidized to $\mathrm{Cl}_{2}$ in the presence of $\mathrm{O}_{2}$ and $\mathrm{H}_{2} \mathrm{O}$ (Ticknor et al. 2014). Oxidation of $\mathrm{Hg}$ by reaction with $\mathrm{HCl}$ takes place in flue gas within the range of temperatures from $500^{\circ} \mathrm{C}$ to $900^{\circ} \mathrm{C}$ (Senior et al. 2000). Hall et al. (1991) and Sliger et al. (2000) demonstrated that the degree of mercury oxidation increases with the increase of the $\mathrm{HCl}$ concentration in gases. However, Widmer et al. (1998) did not find any direct correlation between the $\mathrm{HCl}$ concentration and the degree of $\mathrm{Hg}$ oxidation, particularly at lower gas temperatures. The major difference between both studies was the composition of gases. Hall (Hall et al. 1991) and Sliger (Sliger et al. 2000) examined gases of composition similar to flue gas, whereas Widmer (Widmer et al. 1998) used a synthetic mixture with oxygen, $\mathrm{HCl}, \mathrm{Hg}$ and nitrogen. These results suggested that the kinetics of $\mathrm{HgCl}_{2}$ formation was influenced by concentrations of chlorine and $\mathrm{HCl}$ in flue gases. The reaction including $\mathrm{HCl}$ is one of those potential reactions which can lead to the formation of $\mathrm{HgCl}_{2}$, provided the product of the primary reaction, namely $\mathrm{HgCl}$, is present in the flue gas (Equation 1). In that way, the differences between cited results can be explained. Lack of the primary reaction product $(\mathrm{HgCl})$ makes the reactions between $\mathrm{Hg}$ and $\mathrm{HCl}$ leading to formation of $\mathrm{HgCl}_{2}$ impossible. The reactions occurring in flue gas at temperatures below $600^{\circ} \mathrm{C}$, in which also other flue gas components take part, result in the formation of $\mathrm{HgCl}_{2(\mathrm{~g})}$ and $\mathrm{HgO}_{(\mathrm{g})}$. Not all the elemental mercury in flue gas is subject to oxidation, and some part of $\mathrm{Hg}^{0}$ remains in an unchanged form. Both $\mathrm{Hg}_{(\mathrm{g})}^{0}$ and partially $\mathrm{HgO}_{(\mathrm{g})}$ occur in gases characterized by higher temperatures, however, $\mathrm{HgO}_{(\mathrm{g})}$ is stable at temperatures below $400^{\circ} \mathrm{C}$, whereas $\mathrm{Hg}^{0}{ }_{(\mathrm{g})}$ is stable above $750^{\circ} \mathrm{C}$. At a temperature exceeding $600^{\circ} \mathrm{C}$, in the presence of chloride, $\mathrm{HgO}_{(\mathrm{g})}$ decomposition may take place according to the following reaction:

$$
\mathrm{HgO}_{(\mathrm{g})} \stackrel{680^{0} \mathrm{CCl}}{\longrightarrow} \mathrm{Hg}_{(\mathrm{g})}^{0}+\frac{1}{2} \mathrm{O}_{2(g)}
$$

Hall et al. (1991) found out that, within the range of temperatures from $500^{\circ}$ to $700^{\circ} \mathrm{C}$, nitrogen oxides take part in reactions of oxidation of the elemental mercury, however, the rate of these reactions is lower compared to the rate of reaction of $\mathrm{Hg}^{0}$ with $\mathrm{Cl}_{2}$ and $\mathrm{HCl}$. Therefore, it is believed that these compounds have minor impact on homogeneous oxidation of $\mathrm{Hg}^{0}$. Higher $\mathrm{NO}_{2}$ concentration (ca. 1,000 ppm) causes oxidation of ca. $10 \%$ of $\mathrm{Hg}^{0}$ at $340^{\circ} \mathrm{C}$. Sliger et al. (2000) have showed that the presence of other components in flue gas, namely $\mathrm{CO}_{2}, \mathrm{H}_{2} \mathrm{O}$, and $\mathrm{O}_{2}$, reduces the efficiency of the mercury oxidation process. $\mathrm{SO}_{2}$ does not directly react with $\mathrm{Hg}^{0}$ in flue gas, but the presence of this compound in flue gas reduces the amount of elemental mercury being oxidized as a consequence of the reaction with $\mathrm{HCl}$ (Ghorishi 1998, Edwards et al. 2001, Naruse et al. 2010). Similar dependences were observed while studying the impact of steam on mercury oxidation (Ghorishi 1998). However, the presence of CO in flue gas contributes to formation of $\mathrm{Cl}$ and $\mathrm{HgCl}_{2}$ (Edwards et al. 2001).
In the course of a laboratory-scale study on the influence of concentration of $\mathrm{Cl}, \mathrm{SO}_{2}, \mathrm{HCl}$, and fly ash on speciation of $\mathrm{Hg}$ in gases of compositions similar to the flue gas emitted in the coal combustion process, Laudal et al. (2000) found that the presence of chlorine in the gas caused an increase in the ionized mercury forms in total mercury content in gas to the level of ca. $85 \%$. On the other hand, reduction of $\mathrm{Hg}^{+2}$ concentration to the level of $1 \%$ was also observed when fly ash was present. The same relation was observed in cases of $\mathrm{SO}_{2}$ being present in gases. Laudal and co-authors (Laudal et al. 2000) did not determine any influence of $\mathrm{HCl}$ concentration on the efficiency of the $\mathrm{Hg}$ oxidation reaction. Studies on $\mathrm{Hg}$ transformations in gases in a form of mixtures of fly ash, $\mathrm{Cl}_{2}$, and $\mathrm{SO}_{2}$ revealed that the $\mathrm{Hg}^{2+}$ represented $25.5 \%$ of the total mercury content. This fraction was lower when compared to the results obtained while testing gases containing $\mathrm{Cl}_{2}$ only, but higher than those obtained in studies where the gas contained fly ash or $\mathrm{SO}_{2}$. All these results suggest that the presence of $\mathrm{SO}_{2}$ and fly ash in gases hamper and/or slow down reactions of mercury oxidation. Similar behaviour of mercury was observed while testing gases with $\mathrm{SO}_{2}, \mathrm{HCl}$, and $\mathrm{Cl}_{2}$ (Laudal et al. 2000).

Other components present in flue gas are nitric oxides ( $\mathrm{NO}$ and $\mathrm{NO}_{2}$ ). In the gases containing mercury vapours and nitric oxides only, the oxidized forms of mercury constituted about $2.5 \%$ of total $\mathrm{Hg}$ concentration, whereas the addition of fly ash and chlorine to the gas caused an increase in $\mathrm{Hg}^{+2}$ content to $78.5 \%$. Such considerable content of $\mathrm{Hg}^{+2}$ in gases highlights the major role of chlorine in the mercury oxidation reactions. However, it is noted that the results obtained by Laudal et al. (2000) were based on examinations of synthetic gas conducted at a temperature not corresponding to the actual flue gas temperature. Bearing in mind the impact of the flue gas temperature on the kinetics of the oxidation reaction, it is impossible to make a direct reference between the results thus obtained and the conditions of combustion (Niksa et al. 2001) make the reactions with $\mathrm{HCl}$ leading to formation of $\mathrm{HgCl}_{2}$ impossible.

\section{Impact of temperature and carbon content on $\mathrm{Hg}$ speciation}

Numerous studies have also been conducted on establishing the impact of flue gas temperature on the speciation of mercury emitted in coal combustion processes (Hall et al. 1991, Frandsen et al. 1994, Dajnak et al. 2003, Tan et al. 2004, Wang et al. 2010). In the process within the range of temperatures from $250^{\circ} \mathrm{C}$ to $400^{\circ} \mathrm{C}$ with lignite and subbituminous coals characterized by high chlorine content, mercury is mainly removed as $\mathrm{Hg}^{0}$ (Tan et al. 2004), whereas in the flue gas emitted in combustion of the bituminous coal, and cooled to the temperature of $200^{\circ} \mathrm{C}, 80 \%$ of the total mercury present in the gaseous phase is in its oxidized forms (Tan et al. 2004, Wang et al. 2010). Because of lower temperature of flue gas and higher chlorine concentration, ca. $75 \%$ of $\mathrm{Hg}$ becomes bound with particulate matter, forming $\mathrm{Hg}_{\mathrm{p}}$. The presence of chlorine in flue gas determines the mercury oxidation reactions as well as the physical speciation of $\mathrm{Hg}$. The presence of chlorine results in decrease in the temperature of mercury transformation from the solid to the gaseous phase. Frandsen et al. (1994) have proposed a model of conversion of mercury compounds in flue gas at temperatures below $450^{\circ} \mathrm{C}$. 


$$
\begin{gathered}
\mathrm{HgO}_{(g)} \stackrel{320^{\circ} \mathrm{C}}{\longrightarrow} \mathrm{Hg}_{(\mathrm{g})}^{0}+\frac{1}{2} \mathrm{O}_{2(g)} \\
\mathrm{HgCl}_{2(g)}+\mathrm{H}_{2} \mathrm{O}_{(g)} \stackrel{430^{\circ} \mathrm{C} \mathrm{Cl} l^{-}}{\longrightarrow} \mathrm{HgO}_{(g)}+2 \mathrm{HCl}_{(g)} \\
\mathrm{HgSO}_{4(s)} \stackrel{320^{\circ} \mathrm{C}}{\longrightarrow} \mathrm{HgO}_{(g)}+\mathrm{SO}_{2(g)}+\frac{1}{2} \mathrm{O}_{2(g)} \\
\mathrm{HgO}_{(s)} \stackrel{170^{\circ} \mathrm{C}}{\longrightarrow} \mathrm{HgO}_{(g)} \oplus \\
\mathrm{HgSO}_{4(s)}+\mathrm{Cl}_{2(g)} \stackrel{110^{\circ} \mathrm{C}}{\longrightarrow} \mathrm{HgCh}_{2(g)}+\mathrm{SO}_{2(g)}+\mathrm{O}_{2}
\end{gathered}
$$

$\oplus$ - excluding $\mathrm{HgSO}_{4(\mathrm{~g})}$ presence, $(\mathrm{s})$ - solid phase, (g) gaseous phase

The presence of $\mathrm{HgSO}_{4(\mathrm{~s})}$ and $\mathrm{HgO}_{(\mathrm{s})}$ is thermodynamically justified within flue gas temperatures from $110^{\circ} \mathrm{C}$ to $320^{\circ} \mathrm{C}$ (Frandsen et al. 1994). Based on equilibrium calculations for temperatures below $125^{\circ} \mathrm{C}$, Dajnak et al. (2003) concluded that $\mathrm{HgSO}_{4(\mathrm{~s})}$ is the main form of mercury condensed from flue gas components. They also found that mercury condenses as $\mathrm{HgCl}_{2}$ at temperatures between $125^{\circ} \mathrm{C}$ and $520^{\circ} \mathrm{C}$, and it occurs mainly in elemental form at temperatures above $520^{\circ} \mathrm{C}$.

Senior et al. (2000) observed that mercury transformations also depend on the flue gas cooling rate. Higher efficiency of $\mathrm{Hg}$ oxidation was observed when the gas cooling rate was lower. For the gas cooling rate of $73^{\circ} \mathrm{C} / \mathrm{s}$, the $\mathrm{Hg}$ conversion factor came to $24 \%$, whereas at a cooling rate of $250^{\circ} \mathrm{C} / \mathrm{s}-10.5 \%$ of $\mathrm{Hg}$ became oxidized in a comparable period of time. Hall et al. (1991) proved that the mercury oxidation rate depends on temperature of gases. An increase in the gas temperature results in increase of the oxidation rate. Such a relation has been observed up to the gas temperature of $900^{\circ} \mathrm{C}$.

\section{Heterogeneous reactions}

It is claimed that mercury can be oxidized in flue gas by catalytic heterogeneous reactions leading to the formation of $\mathrm{Hg}^{2+}$ (Liu et al. 2001, Meij et al. 2002, Pavlish et al. 2003, Laumb et al. 2004, Park et al. 2008, Bhardwaj et al. 2009, Gao et al. 2013). These reactions are initiated in flue gas which is cooled to a temperature below $600^{\circ} \mathrm{C}$. Numerous publications indicate a strong relation between the chlorine content in coal, the concentration of $\mathrm{Hg}^{+2}$ in flue gas, and the amount of $\mathrm{Hg}$ bound with the solid phase (Liu et al. 2001, Meij et al. 2002, Pavlish et al. 2003, Park et al. 2008). Higher chlorine content in coal leads to increased efficiency of $\mathrm{Hg}$ oxidation, and also to a higher content of fly ash-bound mercury. Results from the studies focused on mercury conversion in flue gas discussed by Fujiwara et al. (2002) have proved that only combustion of coals with considerable chlorine content leads to the formation of large amounts of mercury in its oxidized form, however, the observed $\mathrm{Hg}$ oxidation efficiency did not rise with the increase of the time of $\mathrm{Hg}$ remaining in flue gas. In the case of flue gas cooling, distribution of mercury between solid and the gaseous phase changes towards an increase in the content of solid particle-bound $\mathrm{Hg}$. Efficiency of heterogeneous reactions of mercury oxidation depends on a number of factors, including flue gas temperature and its composition, mainly on the concentration of $\mathrm{NO}_{2}, \mathrm{HCl}, \mathrm{NO}$ and $\mathrm{SO}_{2}$ (Hall et al. 1991, Galbreath and Zygarlicke 1996, Galbreath and Zygarlicke 2000, Dajnak et al. 2003) as well as on the specific surface area of grains and the content of minerals and unburned carbon in fly ash (Pavlish et al. 2003).

The results of studies undertaken by Galbreath and coworkers (Galbreath et al. 2004) indicate that the addition of $100 \mathrm{ppm}$ of $\mathrm{HCl}$ to the flue gas increased the efficiency of the mercury oxidation reactions as well as mercury adsorption on fly ash surfaces. Heterogeneous reactions with chlorine and mercury may be divided into two groups: (i) direct binding of mercury on the surface and (ii) indirect $\mathrm{Hg}$ oxidation as a consequence of the heterogeneous reaction on the coal surface containing $\mathrm{Cl}$ atoms, leading to the formation of $\mathrm{Cl}_{2}$ (Gao et al. 2013). The heterogeneous submechanism of oxidation assumes that chlorine atoms are substituted with mercury atoms on the surface of coal. Results of some studies (Hower et al. 2000, Sakulpitakphon et. Al. 2000, Mardon and Hower 2004, Mastalerz et al. 2004, Lopez-Anton et al. 2007, Suárez-Ruiz and Parra 2007, Suárez-Ruiz et al. 2007, Hower et al 2010) suggest that the unburned carbon $\left(\mathrm{C}^{\mathrm{uc}}\right)$ facilitates the conversion of $\mathrm{HCl}$ in flue gas into chlorine derivatives of carbon which may react with elemental mercury according to the following reaction patterns (Lopez-Anton et al. 2009):

$$
\begin{gathered}
\mathrm{HCl}+\mathrm{C}^{\mathrm{uc}} \rightarrow \mathrm{ClC}^{\mathrm{uc}}+H \\
\mathrm{ClC}^{\mathrm{uc}}+\mathrm{ClC}^{\mathrm{uc}} \rightarrow \mathrm{Cl}_{2}+2 C^{\mathrm{uc}} \\
\mathrm{Hg}^{0}+\mathrm{ClC}^{\mathrm{uc}} \rightarrow \mathrm{HgClC}^{\mathrm{uc}}
\end{gathered}
$$

An XPS analysis revealed that chlorine on coal surfaces occurs in a form of chlorides as well as in organic forms (Laumb et al. 2004).

The efficiency of heterogeneous reactions taking place on the surface of fly ash also depends on the flue gas composition, and particularly on the concentration of $\mathrm{NO}_{2}, \mathrm{HCl}, \mathrm{NO}$, and $\mathrm{SO}_{2}$ (Norton et al. 2003, Hower et al. 2010, Fuente-Cuesta et a. 2012). The study undertaken by Norton et al. (2003) into the influence of flue gas components on mercury oxidation in gases with vapours of $\mathrm{Hg}, \mathrm{NO}, \mathrm{NO}_{2}, \mathrm{CO}, \mathrm{CO}_{2}, \mathrm{O}_{2}$, and $\mathrm{H}_{2} \mathrm{O}$, transferred through fly ash filters of different carbon content and different specific surface area at the temperature of $180^{\circ} \mathrm{C}$, has shown that $\mathrm{NO}_{2}, \mathrm{HCl}$, and $\mathrm{SO}_{2}$ facilitate mercury oxidation in heterogeneous reactions, whereas the oxidation reaction efficiency decreases in the presence of NO. Moreover, a decline in the oxidation efficiency was observed (only $1 \%$ of elemental mercury was subject to oxidation) when there was no ash in the gas, whereas in the presence of fly ash of carbon content of $3.6 \%$ and specific surface area of $3.4 \mathrm{~m}^{2} / \mathrm{g}, 14 \%$ of mercury was oxidized. Utilization of a fly ash filter with low carbon content of $0.08 \%$ and low specific surface area of $1.5 \mathrm{~m}^{2} / \mathrm{g}$ resulted in oxidation of $4 \%$ of elemental mercury in the gas. The results clearly show that by increasing the carbon content in the fly ash and by expanding its specific surface area, it is possible to raise the efficiency of the mercury oxidation reaction in flue gases. 
Results from the studies aimed to evaluate the influence of gas temperatures on the efficiency of the oxidation reaction showed that a drop in the gas temperature to $120^{\circ} \mathrm{C}$ caused an increase in the mercury oxidation efficiency up to a level of $10 \%$ for fly ash with low carbon content and small specific surface area. It was also found out that lower flue gas temperatures facilitated mercury adsorption on the solid particulates, while oxidation of adsorbed $\mathrm{Hg}$ took place at temperatures below $150^{\circ} \mathrm{C}$ (Norton et al. 2003).

Together with heterogeneous mercury oxidation reactions, reactions with $\mathrm{HCl}$, oxygen, or $\mathrm{NO}_{2}$ may also take place, leading to the development of reactive forms contributing to heterogeneous mercury oxidation. Dunham et al. (2003) and Olson et al. (2005) proposed a detailed mechanism of heterogeneous $\mathrm{Hg}$ oxidation reactions occurring in the presence of $\mathrm{NO}_{2}$ and $\mathrm{SO}_{2}$. In the presence of $\mathrm{NO}_{2}$, elemental mercury is catalytically oxidized into coal surface-bound $\mathrm{Hg}\left(\mathrm{NO}_{3}\right)_{2}$, whereas in the presence of $\mathrm{SO}_{2}$, mercury is converted into its sulphate form. The sulphur compounds in flue gas together with $\mathrm{HCl}$ displace chlorine from the coal surface, thus increasing the content of oxidized forms of mercury in flue gas. What still requires explanation is the thermodynamic and kinetic constraints in mercury and chlorine interrelations in flue gas.

Heterogeneous reactions are catalysed by certain ash components. Iron oxides and/or calcium and copper compounds in the ash can catalyse these types of reactions (Ghorishi and Gullett 1998, Niksa and Fujiwara 2005, Senior 2006, Zhuang et al. 2007, Abad-Valle et al. 2011). The catalytic effect of $\mathrm{CuO}$ and $\mathrm{Fe}_{2} \mathrm{O}_{3}$ is increased as a consequence of the presence of $\mathrm{HCl}$ and $\mathrm{NO}_{x}$ in the flue gas (Bhardwaj et al. 2009). Diversified influence of iron compounds on the catalytic reactions taking place in flue gas has also been observed and, therefore, the addition of hematite contributes to mercury oxidation while the addition of hematite and $\mathrm{NO}_{2}$ inhibits reactions of this type (Galbreath et al. 2004). Dunham et al. (2003), on the other hand, found a correlation between the content of magnetite in ash and $\mathrm{Hg}$ oxidation, and the results of their studies indicate that efficiency of the $\mathrm{Hg}$ oxidation reaction increases with the increase of the magnetite content in the ash. Based on that, a suggestion has been made that iron oxide in spineltype structures in fly ash facilitates mercury oxidation. No catalytic effect has been observed in the cases of $\mathrm{SiO}_{2}, \mathrm{Al}_{2} \mathrm{O}_{3}$, and $\mathrm{Ca}(\mathrm{OH})_{2}$ (Ghorishi and Gullett 1998), whereas Lee et al. (2000) have determined that in the presence of $\mathrm{NO}_{\mathrm{x}}$ both $\mathrm{SiO}_{2}$ and $\mathrm{Al}_{2} \mathrm{O}_{3}$ display catalytic properties for the reactions of $\mathrm{Hg}$ oxidation. Other inorganic ash components with catalytic properties towards airborne mercury do not display them in the case of flue gas.

The iron which is present in fuels catalyses oxidation and binds mercury. In the combustion process, on the other hand, calcium reacts with chlorine, thus leading to the formation of $\mathrm{CaCl}_{2}$, and this reaction is competitive with the reaction of $\mathrm{Hg}$ oxidation by chlorine. While studying transformations of subbituminous coal with $\mathrm{CaCl}_{2}$ additives, Zhaung et al. (2007) arrived at a conclusion that addition of this compound resulted in oxidation of ca. $50 \%$ of the elemental mercury in flue gas. These reactions are responsible for high $\mathrm{Hg}^{0}$ content in the total emission of mercury from combustion of lignite and subbituminous coals characterized by high calcium content and low chlorine content. In the study on thermal stabilisation of mercury retained on the fly ash, Rubel et al. (2005) demonstrated thermal stability of mercury in ash samples up to $300^{\circ} \mathrm{C}$. Results of their studies suggest a correlation between the efficiency of mercury retention on the fly ash and the increase of its sulphur and carbon content. It has also been determined that the carbon content in fly ash is responsible for predominant form of $\mathrm{Hg}$ sorption, i.e. chemisorption of this element. The presence of sulphur in fly ash, on the other hand, causes $\mathrm{Hg}$ deposition in the form of sulphur compounds.

\section{Mercury adsorption on the fly ash surface}

As mentioned above, fly ash takes part in heterogeneous oxidation of mercury. It is also mercury adsorbent, but the adsorption capacity of inorganic fly ash fractions is low for mercury. The numerous attempts made to determine the relation between carbon or volatile matter content and the efficiency of gaseous mercury sorption on the ash, in most cases have indicated considerable influence of the specific surface area, the content of mineral particulate fractions in the ash, and the flue gas temperature (Baochun et al. 2000, Gibb et al. 2000, Fujiwara et al. 2002, Dunham et al. 2003, Tan et al. 2004, Maroto-Valer et al. 2005, Rubel et al. 2005, Rubel et al. 2006, Wang et al. 2007, Hower et al 2010, Abad-Valle et al. 2011). Mercury in the form of $\mathrm{HgO}$ and $\mathrm{Hg}^{2+}$ may be subject to partial sorption on the fly ash which contains considerable quantities of unburned carbon, and such phenomenon was observed in hot flue gas, above the temperature of $500^{\circ} \mathrm{C}$ (Baochun et al. 2000, Fujiwara et al. 2002, Wang et al. 2007, Abad-Valle et al. 2011). In the measurements conducted during coal combustion in a $1 \mathrm{MW}$ furnace, Gibb et al. (2000) found out a relation between the carbon content in the ash and the efficiency of sorption on its surface. Results of their studies suggest that nearly $100 \%$ of mercury emitted from coal combustion was retained on the surface of the ash which contained more than $5 \%$ of unburned carbon. They demonstrated a linear correlation between a decline in the flue gas temperature and an increase in the $\mathrm{Hg}$ content in fly ash within the range of flue gas temperatures from $150^{\circ} \mathrm{C}$ to $450^{\circ} \mathrm{C}$ (Gibb et al. 2000 , Rubel et al. 2005). Additionally, they found out that the efficiency of $\mathrm{Hg}$ sorption on fly ash increased with the time of effective contact between flue gas and fly ash (Rubel et al. 2006). Tan et al. (2004), in a study on mercury speciation in the flue gas emitted in coal combustion in a vertical combustion chamber, found that $12 \%$ of the total emitted mercury was subject to sorption on the surface of high-carbon ash.

No relation between the chlorine content in coal and the efficiency of mercury retention on the particulate was observed (Hower et al. 2010), however the results of studies by Dunham et al. (2003) show that sorption capacity of the ash emitted in the coal combustion process is very similar to $\mathrm{HgCl}_{2}$ and $\mathrm{Hg}^{0}$, and that it increases with the temperature decrease. Other relations were established by Baochum et al. (2000) while testing adsorption of gaseous mercury on the ash within the temperature range from $70^{\circ} \mathrm{C}$ to $160^{\circ} \mathrm{C}$. They suggest that, under identical conditions and depending on the type of coal from which the ash has been produced, adsorption of mercury in the form of $\mathrm{HgCl}_{2}$ is ca. 2 to 50 times more effective than $\mathrm{Hg}^{0}$ adsorption. Adsorption of $\mathrm{HgCl}_{2}$ is less dependent on carbon content in the coal from which the ash was produced and depends more on the ash specific surface area (Galbreath and Zygarlicke 2000). The results thus obtained show that 
sorption of $\mathrm{HgCl}_{2}$ on the surface of ash is a physical adsorption process.

The phenomenon of mercury adsorption on the ash is also affected by the flue gas composition. Wang et al. (2007) found out that high concentration of ammonia in gas limited mercury adsorption, in the result of the formation of a mercury-ammonia complex, characterized by lower capacity for adsorption on solid particulates.

\section{Conclusions}

Mercury transformation mechanisms and speciation characteristics were reviewed for mercury compounds emitted in flue gas from coal-fired boilers. As confirmed in numerous publications, chemical conversion of mercury and its compounds into flue gas indicate that in the combustion process three main stages of different kinetics and reaction mechanisms can be distinguished. The first one is the stage of mercury evaporation from fuel, when decomposition of mercury compounds takes place together with reactions leading to the formation of elemental mercury $\left(\mathrm{Hg}^{0}\right)$. This stage takes place at temperatures exceeding $700^{\circ} \mathrm{C}$. The second stage comprises homogeneous reactions of $\mathrm{Hg}^{0}$ oxidation with other active flue gas components, predominantly $\mathrm{HCl}$, which leads to the formation of $\mathrm{HgCl}_{2}$ and $\mathrm{HgO}$. These reactions take place mainly at a temperature below $600^{\circ} \mathrm{C}$, and their kinetics depends on the concentration of flue gas components. Heterogeneous reactions with participation of mercury, both in the elemental and the oxidized form, and leading to the generation of particulate-bound forms of $\mathrm{Hg}$, take place at temperatures below $600^{\circ} \mathrm{C}$. However, the particulate-bound form is stable up to a flue gas temperature of about $300^{\circ} \mathrm{C}$. Both homo- and heterogeneous reactions depend on the concentration of gaseous components of flue gas, while the heterogeneous ones depend also on fly ash properties, such as the content of elemental carbon and mineral fraction as well as the specific surface area of ash particles.

Awareness of the issue of mercury as a global pollutant is growing and, as a result, emission reduction requirements are becoming more common. Thus, the explanation of the mechanisms of mercury release in coal combustion units is a fundamental part of an emission-control strategy. Although there are a number of different technical approaches to remove mercury from flue gas, there is no single best technology that can be implemented broadly. Most of the discussed here issues concerning transformation of mercury and its compounds in coal combustion have a substantial connection with decisions on selection of a method of mercury emission reduction to the atmosphere. Having in mind this knowledge one can decide if a better choice is a particulate emission control technique, an adsorption or absorption method as a mercury emission control technology.

\section{References}

Abad-Valle, J.P., Lopez-Anton, M.A., Diaz-Somoano, M., Juan, R., Rubio, B., Garcia, J.R., Khainakov, S.A. \& Martínez-Tarazona, M.R. (2011). Influence of iron species present in fly ashes on mercury retention and oxidation, Fuel, 90, pp. 2808-2811.

Abad-Valle, J.P., López-Antón, M.A., Díaz-Somoano, M. \& Martínez-Tarazona, M.R. (2011). The role of unburned carbon concentrates from fly ashes in the oxidation and retention of mercury, Chemical Engineering Journal, 174, pp. 86-92.

Agarwal, H. \& Stenger, H.G. (2007). Development of a predictive kinetic model for homogeneous $\mathrm{Hg}$ oxidation data, Mathematical and Computer Modelling, 45 (1-2), pp. 109-125.

Ariya, P.A., Khalizov, A. \& Gidas, A.J. (2002). Reactions of gaseous mercury with atomic and molecular halogens: kinetics, product studies, and atmospheric implications, The Journal of Physical Chemistry A, 106, pp. 7310-7320.

Baochun, W., Thomas, P., Shadman, W., Farhang, A., Senior, C.L. \& Morency, J.R. (2000). Interactions between vapor-phase mercury compounds and coal char in synthetic flue gas, Fuel Processing Technology, 63, pp. 93-107.

Bełdowska, M., Saniewska, D., Falkowska, L. \& Lewandowska, A. (2012). Mercury in particulate matter over Polish zone of the southern Baltic Sea, Atmospheric Environment, 46, pp. 397-404.

Bhardwaj, R., Chen, X. \& Vidic, R.D. (2009). Impact of fly ash composition on mercury speciation in simulated flue gas, Journal of the Air \& Waste Management Association, 59(11), pp. 1331-1338.

Bojakowska, I. \& Sokołowska, G. (2001). Mercury in mineral raw materials exploited in Poland as potential sources of environmental pollution, Biuletyn PIG 394, pp. 5-54. (in Polish)

Cao, Y., Chin-Min Cheng, C-M., Chen, C-W., Liu, M., Wang, C. \& Pan, W-P. (2008). Abatement of mercury emissions in the coal combustion process equipped with a Fabric Filter Baghouse, Fuel, 87, pp. 3322-3330.

Cauch, B., Silcox, G.D., Lighty, J.S., Wendt, J.O.L., Fry, A. \& Senior, C.L. (2008), Environmental Science \& Technology, 42, pp. 2594-2599.

Chow, W., Mill, M.J. \& Torrens, I.M. (1994). Pathways of trace elements in power plants: interim research results and implications, Fuel Processing Technology, 39, pp. 5-20.

Council of Ministers of the Environment (2006). Canada-wide Standards for Mercury Emissions from Coal-fired Electric Power Generation Plants. (http://www.ccme.ca/files/Resources/air/ mercury/hg_epg_cws_w_annex.pdf(11.10.2016)).

Dajnak, D., Clark, K.D., Lockwood, F.C. \& Reed, G. (2003). The prediction of mercury retention in ash from pulverised combustion of coal and sewage sludge, Fuel, 82, pp. 1901-1909.

Dunham, G.E., De Wall, R.A. \& Senior, C.L. (2003). Fixed-bed studies of the interactions between mercury and coal combustion fly ash, Fuel Processing Technology, 82, pp. 197-213.

Edwards, J.R., Srivastava, R.K. \& Kilgroe, J.A. (2001). Study of gas-phase mercury speciation using detailed chemical kinetics, Journal of the Air \& Waste Management Association, 51, pp. 869-877.

Eom, Y., Jeon, S.H., Ngo, T.A., Kim, J. \& Lee, T.G. (2008). Heterogeneous mercury reaction on a Selective Catalytic Reduction (SCR) Catalyst, Catalysis Letters, 121, pp. 219-225.

Finkelman, R.B. (1994). Mode of occurrence of potentially hazardous elements in coal: levels of confidence, Fuel Processing Technology, 39, pp. 21-34.

Frandsen, F., Dam-Johansen, K. \& Rasmussen, P. (1994). Trace elements from combustion and gasification of coal an equilibrium approach, Progress in Energy and Combustion Science, pp. 115-138.

Fuente-Cuesta, A., Lopez-Anton, M.A., Diaz-Somoano, M. \& Martínez-Tarazona, M.R. (2012). Retention of mercury by low-cost sorbents: Influence of flue gas composition and fly ash occurrence, Chemical Engineering Journal, 213, pp. 16-21.

Fujiwara, N., Fujita, Y., Nomura, K., Moritomi, H., Tuzi, T. \& Takasu, S. (2002). Mercury transformations in the exhausts from lab-scale coal flames, Fuel, 81, pp. 2045-2052.

Galbreath, K.C. \& Zygarlicke, C.J. (1996). Mercury speciation in coal combustion and gasification flue gases, Environmental Science \& Technology, 30, pp. 2421-2426. 
Galbreath, K.C. \& Zygarlicke, C.J. (2000). Mercury transformations in coal combustion flue gas, Fuel Processing \& Technology, 66, pp. 289-310.

Galbreath, K., Zygarlicke, C.J., Tibbetts, J.E., Schulz, R.L. \& Dunham, G.E. (2004). Effects of NOx, $\alpha-\mathrm{Fe}_{2} \mathrm{O}_{3}, \gamma-\mathrm{Fe}_{2} \mathrm{O}_{3}$, and $\mathrm{HCl}$ on mercury transformations in a $7-\mathrm{kW}$ coal combustion system, Fuel Processing Technology, 86(4), pp. 429-448.

Gao, Y., Zhang, Z., Wu, J., Duan, L., Umar, A., Sun, L., Guo, Z. \& Wang, Q. (2013). A critical review on the heterogeneous catalytic oxidation of elemental mercury in flue gases, Environmental Science Technology, 47, pp. 10813-10823.

Ghorishi, S.B. (1998). Fundamentals of Mercury Speciation and Control in Coal-Fired Boilers. EPA Report number EPA-600/R-98-014 (NTIS PB98-127095), February 1998.

Ghorishi, B. \& Gullett, B.K. (1998). Sorption of mercury species by activated carbons and calcium-based sorbents: effect of temperature, mercury concentration, and acid gases, Waste Management \& Research, 16, pp. 582-593.

Gibb, W.H., Clarke, F. \& Mehta, A.K. (2000). The fate of coal mercury during combustion, Fuel Processing Technology, 65, pp. 365-377.

Hall, B., Schager, P. \& Lindqvist, E. (1991). Chemical reactions of mercury in combustion flue gases, Water Air \& Soil Pollution, 56, pp. 3-14.

Hlawiczka, S. \& Fudala, J. (2008). Assessment of atmospheric mercury emission reduction measures relevant for application in Poland, Environmental Engineering Science, 2, pp. 163-171.

Hlawiczka, S., Kubica, K. \& Zielonka, U. (2003). Partitioning factor of mercury during coal combustion in low capacity domestic heating units, Science of the Total Environment, 312, pp. 261-265.

Horne, D.G., Gosavi, R. \& Strauss, O.P. (1968). Reactions of metal atoms. I. The combination of mercury and chlorine atoms and the dimerization of mercuries chloride, Journal of Chemical Physics, 48 (10), pp. 4758-4764.

Hower, J.C., Maroto-Valer, M.M., Taulbee, D.N. \& Sakulpitakphon, T. (2000). Mercury capture by distinct fly ash carbon forms, Energy \& Fuels, 14, pp. 224-226.

Hower, J.C., Senior, C.L., Suuberg, E.M., Hurt, R.H., Wilcox, J.L. \& Olson, E.S. (2010). Mercury capture by native fly ash carbons in coal-fired power plants, Progress in Energy and Combustion Science, pp. 510-529.

Ito, S., Yokoyama, T. \& Asakura, K. (2006). Emissions of mercury and other trace elements from coal-fired power plants in Japan, Science of the Total Environment, 368, pp. 397-402.

Jang, H.N., Kimb, J.H., Jung, S.J., Back, S.K., Sung, J.H., Kim, S.H., Seo, Y.C., Keel, S.I. \& Liu, X. (2014). Mercury emission characteristics from coal combustion by supplying oxygen and carbon dioxide with limestone injection, Fuel Processing Technology, 125, pp. 217-222.

Jones, C. (1994). Consensus on air toxics eludes industry to date, Power, 138, pp. 51-59.

Józewicz, W. (2007). Control of Mercury Emissions from Coal-fired Power Plants. Monography. PZITS Oddział Wielkopolski. Poznań 2007.

Kabata-Pendias, A. \& Pendias, H. (1999). Biogeochemistry of trace elements. PWN Warszawa 1999. (in Polish)

Pan, W-P., Cao, Y. \& Zhang, K. (2013). Mercury Emission, Control and Measurement from Coal Combustion, pp. 29-36, In: Cleaner Combustion and Sustainable World, Qi, H. \& Zhao, B. (Eds.) Springer-Verlag Berlin Heidelberg \& Tsinghua University Press, 2013.

Kilgroe, J.D., Sedman, C.B., Srivastava, R.K., Ryan, J.V., Lee, C.W. \& Thorneloe, S.A. (2002). Control of Mercury Emissions from Coal-Fired Electric Utility Boilers: Interim Report Including Errata Data 3-21-02, April 2002, EPA-600/R-01-109.
Kolker, A., Senior, C.L. \& Quick, J.C. (2006). Mercury in coal and the impact of coal quality on mercury emissions from combustion systems, Applied Geochemistry, 21, pp. 1821-1836.

Kolker, A., Panov, B.S., Panov, Y.B., Landa, E.R., Conko, K.M., Korchemagin, V.A., Shendrik, T. \& Mccord, J.D. (2009). Mercury and trace element contents of Donbas coals and associated mine water in the vicinity of Donetsk Ukraine, International Journal of Coal Geology, 79, pp. 83-91.

Laudal, D.L., Brown, T.D. \& Nott, B.R. (2000). Effects of flue gas constituents on mercury speciation, Fuel Processing Technology, 65-66, pp. 157-165.

Laumb, J.D., Benson, S.A. \& Olson, E.A. (2004). X-ray photoelectron spectroscopy analysis of mercury sorbent surface chemistry, Fuel Processing Technology, 85(6-7), pp. 577-585.

Leaner, J.J., Dąbrowski, J.M., Mason, R.P., Resane, T., Richardson, M., Ginster, M., Gericke, G., Petersen, C.R., Masekoameng, E., Ashton, P.J. \& Murray, K. (2009). Mercury Emissions from Point Sources in South Africa, In: Mercury Fate and Transport in the Global Atmosphere, Pirrone, N. \& Mason, R. (eds.), Springer.

Lee, C.W., Kilgroe, J.D. \& Ghorishi, S.B. Speciation of mercury in the presence of coal and waste combustion fly ashes, Report EPA-68-C-99-201, Triangle Park, NC. Environmental Protection Agency 2000

Lee, C.W., Srivastava, R.K., Ghorishi, S.B., Karwowski, J., Hastings, T.W. \& Hirschi, J.C. (2006). Pilot-scale study of the effect of selective catalytic reduction catalyst on mercury speciation in Illinois and Powder River Basin coal combustion flue gases, Journal of the Air \& Waste Management Association, 56, pp. 643-649.

Li, L.C., Deng, P., Tian, A.M., Xu, M.H., Zheng, C.G. \& Wong, N.B. (2003). A study on the reaction mechanism and kinetic of mercury oxidation by chlorine species, Journal of Molecular Structure: THEOCHEM, 625, pp. 277-281.

Liu, K., Gao, Y., Kellie, S., Pan, W.P. \& Riley, J.T.A. (2001). Study of mercury removal in FBC systems fired with high-chlorine coals, Combustion Science \& Technology, 164, pp. 145-162.

López-Antón, M.A., Díaz-Somoano, M. \& Martínez-Tarazona, M.R. (2007). Retention of elemental mercury in fly ashes in different atmospheres, Energy \& Fuels, 21, pp. 99-103.

López-Antón, M.A., Abad-Valle, P., Díaz-Somoano, M., Suárez-Ruiz, I. \& Martínez-Tarzona, M.R. (2009). The influence of carbon particle type in fly ashes on mercury adsorption, Fuel, 88, pp. 1194-1200.

López-Antón, M.A., Yuan, Y., Perry, R. \& Maroto-Valer, M.M. (2010). Analysis of mercury species present during coal combustion by thermal desorption, Fuel, 89, pp. 629-634.

Mardon, S.M. \& Hower, J.C. (2004). Impact of coal properties on coal combustion by-product quality: examples from a Kentucky power plant, International Journal of Coal Geology, 59 (3-4), pp. $153-169$.

Maroto-Valer, M.M., Zhang, Y., Granite, E.J., Tang, Z. \& Pennline, H.W. (2005). Effect of porous structure and surface functionality on the mercury capacity of a fly ash carbon and its activated sample, Fuel, 84, pp. 105-108.

Mastalerz, M., Hower, J.C., Drobniak, A., Mardon, S.M. \& Lis, G. (2004). From in-situ coal to fly ash: A study of coal mines and power plants from Indiana, International Journal of Coal Geology, 59(3-4), pp. 171-192.

Meij, R., Vredendregt, L.H.J. \& Winkel, H., (2002). The fate and behavior of mercury in coal-fired power plants, Journal of the Air \& Waste Management Association, 52, pp. 912-917.

Mukherjee, A.B., Zevenhoven, R., Bhattacharya, P., Sajwan, K.S. \& Kikuchi, R. (2008). Mercury flow via coal and coal utilization by-products: A global perspective, Resources, Conservation and Recycling, 52, pp. 571-591.

Naruse, I., Yoshiie, R., Kameshima, T., Takuwa, T. \& Mater, J. (2010). Gaseous mercury oxidation behavior in homogeneous reaction 
with chlorine compounds, Journal of Material Cycles and Waste Management, 12, pp. 154-160.

Nelson, P.F. (2007). Atmospheric emissions of mercury from Australian point sources, Atmospheric Environment, 41, pp. 1717-1724.

Niksa, S.C. \& Fujiwara, N.J. (2005). A predictive mechanism for mercury oxidation selective catalytic reduction catalysts under coal-derived flue gas, Journal of the Air \& Waste Management Association, 55, pp. 1866-1875.

Niksa, S.C., Fujiwara, N.J., Fujita, Y., Tomura, K., Moritomi, H., Tuji, T. \& Takasu, S. (2002). A mechanism for mercury oxidation in coal-derived exhausts, Journal of the Air \& Waste Management Association, 52 (8), pp. 894-901.

Niksa, S.C., Helble, J.J. \& Fujiwara, N. (2001). Kinetic modeling of homogeneous mercury oxidation: the importance of $\mathrm{NO}$ and $\mathrm{H}_{2} \mathrm{O}$ in predicting oxidation in coal-derived systems, Environmental Science \& Technology, 35 (18), pp. 3701-3706.

Norton, G.A., Yang, H., Brown, R.C., Laudal, D.L., Dunham, G.E. \& Erjavec, J. (2003). Heterogeneous oxidation of mercury in simulated post combustion conditions, Fuel, 82, pp. 107-116.

Nowak, B., Grzegorczyk, M., Czaplicka, M. \& Zielonka, U. (2013). Comparison of two different analytical procedures for determination of total mercury in wet deposition samples, Environmental Protection Engineering, 39(1), pp. 75-85.

Nowak, B., Korszun-Klak, K. \& Zielonka, U. (2014). Long-term measurements of atmospheric mercury species (TGM, TPM) and $\mathrm{Hg}$ deposition in the Silesian Region, Poland - concept of the mercury deposition coefficient, Archives of the Environmental Protection, 40(3), pp. 43-60.

Olson, E.S., Crocker, C.R., Benson, S.A., Pavlish, J.H. \& Holmes, M.J. (2005). Surface compositions of carbon sorbents exposed to simulated low-rank coal flue gases, Journal of the Air \& Waste Management Association, 55, pp. 747-754.

Pacyna, E.G., Pacyna, J.M., Fudala, J., Strzelecka-Jastrzab, E., Hlawiczka, S. \& Panasiuk, D. (2006). Mercury emissions to the atmosphere from anthropogenic sources in Europe in 2000 and their scenarios until 2020, Science of the Total Environment, 370 , pp. $147-156$.

Pacyna, J.M., Travnikov, O., De Simone, F., Hedgecock, I.M., Sundseth, K., Pacyna, E.G., Steenhuisen, F., Pirrone, N., Munthe, J. \& Kindbom, K. (2016). Current and future levels of mercury atmospheric pollution on a global scale, Atmospheric Chemistry and Physics, 16, pp. 12495-12511.

Park, J.Y., Won, J.H. \& Lee, T.G. (2006). Mercury analysis of various types of coal using acid extraction and pyrolysis methods, Energy Fuels, 20, pp. 2413-2416.

Park, K.S., Seo, Y.C., Lee, S.J. \& Lee, J. (2008). Emission and speciation of mercury from various combustion sources, Powder Technology, 180, pp. 151-156.

Pavlish, J.H., Sondreal, E.A., Mann, M.D., Olson, E.S., Galbreath, K.C., Laudal, D.L. \& Benson, S.A. (2003). Status review of mercury control options for coal-fired power plants, Fuel Process Technology, 82, pp. 89-165.

Pirrone, N., Munthe, J.H., Barregård, L., Ehrlich, H.C., Petersen, G., Fernandez, R., Hansen, J.C., Grandjean, P., Horvat, M., Steinnes, E., Ahrens, R., Pacyna, J.M., Borowiak, A., Boffetta, P. \& Wichmann-Fiebig, M. (2001). Ambient Air Pollution by Mercury (Hg) - Position Paper, Office for Official Publications of the EC (http://europa.eu.int/comm/environment/air/background. htm\#mercury(21.08.2017)).

Praveen, A. (2003). Mercury emissions from coal-fired power plants. The Case for Regulatory Action, Northeast States for Coordinated Air Use Management, Boston (www.nescaum.org/documents/ rpt031104mercury.pdf (21.08.2017)).

Procaccini, C., Bozzelli, J.W., Longwell, J.P., Smith, K.A. \& Sarofim, A.F. (2000). Presence of chlorine radicals and formation of molecular chlorine in the post-flame region of chlorocarbon combustion, Environmental Science \& Technology, 34 (21), pp. $4565-4570$.

Pyta, H., Rosik-Dulewska, Cz. \& Czaplicka, M. (2009). Speciation of Ambient Mercury in the Upper. Silesia Region, Poland, Water, Air \& Soil Pollution, 197(1-4), pp. 233-240.

Rallo, M., Lopez-Anton, M.A., Contreras, M.L. \& Maroto-Valer, M.M. (2012). Mercury policy and regulations for coal-fired power plants, Environmental Science and Pollution Research, pp. 1084-1096.

Rizeq, R., Hansell, D. \& Seeker, W. (1994). Predictions of metals emissions and partitioning in coal-fired combustion systems, Fuel Processing \& Technology, 39, pp. 219-236.

Romanov, A., Sloss, L. \& Józewicz, W. (2012). Mercury emissions from the coal-fired energy generation sector of the Russian Federation, Energy \& Fuels, 26, pp. 4647-4654.

Rubel, A., Andrews, R., Gonzalez, R., Groppo, J. \& Robl, T. (2005). Adsorption of $\mathrm{Hg}$ and $\mathrm{NO}_{\mathrm{x}}$ on coal by-products, Fuel, 84, pp. 911-916.

Rubel, A.M., Hower, J.C., Mardon, S.M., Zimmerer, M.J. \& Matthew, J. (2006). Thermal stability of mercury captured by ash, Fuel, 85 , pp. 2509-2515.

Ruch, R.R., Gluskoter, H.J. \& Shimp, N.F. (1974). Occurrence and distribution of potentially volatile trace elements in coal: a final report. Illinois State Geological Survey 1974, Environment Geology Notes, Catalog No. EG072 (http://library.isgs.illinois. edu/Pubs/pdfs/egs/eg072.pdf(21.08.2017)).

Sakulpitakphon, T., Hower, J.C., Trimble, A.S., Schram, W.H. \& Thomas, G.A. (2000). Mercury capture by fly ash: study of the combustion of a high-mercury coal at a utility boiler, Energy Fuels, 14 (3), pp. 727-733.

Senior, C.L. (2006). Oxidation of mercury across selective catalytic reduction catalysts in coal-fired power plants, Journal of the Air \& Waste Management Association, 56, pp. 23-31.

Senior, C.L. \& Johnson, S.A. (2005). Impact of carbon-in-ash on mercury removal across particulate control devices in coal-fired power plants, Energy Fuels, 19 (3), pp. 859-863.

Senior, C.L., Sarofim, A.F., Zeng, T., Helble, J.J. \& Mamani-Paco, R. (2000). Gasphase transformations of mercury in coal-fired power plants, Fuel Processing Technology, 63(2-3), pp. 197-213.

Sliger, R.N., Kramlich, J.C. \& Marinov, N.M. (2000). Towards the development of a chemical kinetic model for the homogeneous oxidation of mercury by chlorine species, Fuel Processing Technology, 65-66, pp. 423-428.

Sloss, L.L. Legislation, standards and methods for mercury emissions control, IEA Clean Coal Centre. CCC/195. London, UK, April 2012.

Strege, J.R., Zygarlicke, C.J., Folkedahl, B.C. \& McCollor D.P. (2008). SCR deactivation in a full-scale cofired utility boiler, Fuel, 87, pp. 1341-1347.

Suárez-Ruiz, I., Hower, J.C. \& Thomas, G.A. (2007). Hg and Se capture and fly ash carbons from combustion of complex pulverized feed blends mainly of anthracitic coal rank in Spanish power plants, Energy \& Fuels, 21, pp. 59-70.

Suárez-Ruiz, I. \& Parra, J.B. (2007). Relationship between textural properties, fly ash carbons, and $\mathrm{Hg}$ capture in fly ashes derived from the combustion of anthracitic pulverized feed blends, Energy \& Fuels, 21, pp. 1915-1923.

Tan, Y., Mortazavi, R., Dureau, B. \& Douglas, M.A. (2004). An investigation of mercury distribution and speciation during coal combustion, Fuel, 83, 2229-2236.

Tewalt, S.J., Belkin, H.E., SanFilipo, J.R., Merrill, M.D., Palmer, C.A., Warwick, P.D., Karlsen, A.W., Finkelman, R.B. \& Park, A.J. (2010). Chemical analyses in the World Coal Quality Inventory, version 1: U.S. Geological Survey Open-File Report 2010-1196, (http://pubs.usgs.gov/of/2010/1196/).

Ticknor, J. L, Hsu-Kim, H. \& Deshusses, M.A. (2014). A robust framework to predict mercury speciation in combustion flue gases, Journal of Hazardous Materials, 264, pp. 380-385. 
Toole-O’Neil, B., Tewalt, S.J., Finkelman, R.B. \& Akers, D.J. (1999). Mercury concentration in coal - unraveling the puzzle, Fuel, 78, pp. 47-54.

United Nations Environment Programme (2010). Toolkit for identification and quantification of mercury releases. Reference Report and Revised Inventory Level 2. Report including Description of Mercury Source Characteristics, Version 1.0. UNEP Chemicals Branch, Geneva, Switzerland.

United Nations Environment Programme (2011). Reducing mercury emissions from coal combustion in the energy sector. UNEP Chemicals Branch, Geneva, Switzerland.

United Nations Environment Programme (2013a). Global mercury assessment 2013: sources, emissions, releases, and environmental transport. UNEP Chemicals Branch, Geneva, Switzerland.

United Nations Environment Programme (2013b). Reducing mercury emissions from coal combustion in the energy sector of the Russian Federation. UNEP Chemicals Branch, Geneva, Switzerland.

United Nations Environment Programme (2016). Guidance on Best Available Techniques and Best Environmental Practices. Coal-fired power plants and coal-fired industrial boilers. UNEP Chemicals Branch, Geneva, Switzerland.

U.S. Environmental Protection Agency (1997). Mercury Study Report to Congress 1997 (https://www.epa.gov/mercury/mercury-studyreport-congress).

U.S. Environmental Protection Agency (2002). Control of Mercury Emissions from Coal-Fired Electric Utility Boilers: Interim Report Including Errata Dated 3-31-02, EPA-600/R-01-109, Air Pollution Prevention and Control Division, National Risk Management Research Laboratory, Office of Research and Development, Research Triangle Park, NC.

U.S. Environmental Protection Agency Grant No. R828168 (2004). Final Report: Fundamentals of Mercury Speciation Kinetics: A Theoretical and Experimental Study. University of Arizona

U.S. Environmental Protection Agency (2011). National Emission Standards for Hazardous Air Pollutants From Coal- and OilFired Electric Utility Steam Generating Units and Standards of Performance for Fossil-Fuel-Fired Electric Utility, Industrial - Commercial - Institutional, and Small Industrial - Commercial - Institutional Steam Generating Units; Proposed Rule. Federal Register, Vol. 76, No. 85.

Wang, J., Wang, T., Mallhi, H., Liu, Y., Ban, H. \& Ladwig, K. (2007). The role of ammonia on mercury leaching from coal fly ash, Chemosphere, 69, pp. 1586-1592.

Wang, S.X., Zhang, L., Li, G.H., Wu, Y., Hao, J.M., Pirrone, N., Sprovieri, F. \& Ancora, M.P. (2010). Mercury emission and speciation of coal-fired power plants in China, Atmospheric Chemistry and Physics, 10, pp. 1183-1192.

Wichliński, M., Kobyłecki, R. \& Bis, Z. (2013). The investigation of mercury contents in polish coal samples, Archives of Environmental Protection, 39(2), pp. 141-150.
Wichliński, M., Kobyłecki, R. \& Bis, Z. (2014). The release of mercury from polish coals during thermal treatment of fuels in a fluidized bed reactor, Fuel Processing Technology, 119, pp. 92-97.

Wilcox, J., Rupp, E., Ying, S.C., Lim, D.-H., Negreira, A.S., Kirchofer, A., Feng, F. \& Lee, K. (2012). Mercury adsorption and oxidation in coal combustion and gasification processes, International Journal of Coal Geology, 90-91, pp. 4-20.

Widmer, N., Cole, J., Seeker, W. \& Gaspar, J. (1998). Practical limitation of mercury speciation in simulated municipal waste incinerator flue gas, Combustion Science and Technology, 134, pp. 315-326.

Winberg, S., Winthum, J., Tseng, S. \& Locke, J. (2004). Evaluation of mercury emissions from coal-fired facilities with SCR-FGD Systems, DOE/NETL Mercury Control Technology R\&D Program Review, Pittsburgh, PA.

Wojnar, K. \& Wisz, J. (2006). Mercury in the Polish energetic, Energetyka, 59 (4), pp. 280-284. (in Polish)

Wu, C., Cao, Y., Dong, Z., Cheng, C., Li, H. \& Pan, W. (2010). Evaluation of mercury speciation and removal through air pollution control devices of a 190 MW boiler, Journal of Environmental Sciences (China), 22(2), pp. 277-282.

Xu, M., Qiao, Y., Zheng, C., Li, L. \& Liu, J. (2003). Modeling of homogeneous mercury speciation using detailed chemical kinetics, Combustion and Flame - Journal, 132, pp. 208-218.

Yudovich, Y.E. \& Ketris, M.P. (2005a). Mercury in coal: a review: part 1, International Journal of Coal Geology, 62, pp. 107-134.

Yudovich, Y.E. \& Ketris, M.P. (2005b). Mercury in coal: a review: part 2. Coal use and environmental problems, International Journal of Coal Geology, 62, pp. 135-165.

Zhang, L., Wang, S. X., Meng, Y. \& Hao, J.M. (2012). Influence of mercury and chlorine content of coal on mercury emissions from coal-fired power plants in China, Environmental Science and Technology, 46 (11), pp. 6385-6392.

Zhao, Y., Mann, M.D., Olson, E.S., Pavlish, J.H. \& Dunham, G.E. (2006). Effects of sulfur dioxide and nitric oxide on mercury oxidation and reduction under homogeneous conditions, Journal of the Air \& Waste Management Association, 56 (5), pp. 628-635.

Zheng, L., Liu, G. \& Zhou, C. (2007). The distribution, occurrence and environmental effect of mercury in Chinese coals, Science of the Total Environment, 384, pp. 374-383.

Zhuang, Y., Laumb, J., Liggett, R., Holmes, M. \& Pavlish, J.H. (2007a). Impacts of acid gases on mercury oxidation across SCR catalyst, Fuel Processing Technology - Journal, 88, pp. 929-934.

Zhuang, Y., Thompson, J.S., Zygarlicke, C.J. \& Pavlish, J.H. (2004). Development of a mercury transformation model in coal combustion flue gas, Environmental Science \& Technology, 38 (21), pp. 5803-5808.

Zhuang, Y., Thompson, J.S., Zygarlicke, C.J. \& Pavlish, J.H. (2007b). Impact of calcium chloride addition on mercury transformations and control in coal flue gas, Fuel, 86, pp. 2351-2359.

\section{Przemiany rtęci w procesach spalania paliw stałych}

Streszcznie: Artykuł stanowi podsumowanie aktualnego stanu wiedzy nt. kinetyki i mechanizmów reakcji z udziałem rtęci, w tym reakcji homogenicznych i heterogenicznych, zachodzących w spalinach z procesów spalania paliw stałych. Opisano wpływ składników spalin i temperatury na efektywność utleniania rtęci. Omówiono również zagadnienia fizycznej i chemicznej specjacji rtęci w gazach spalinowych, jak również wpływ różnych czynników na specjację rtęci. 